\title{
System Innovation, Corporate Governance and Development Potential of State-owned Enterprise
}

\author{
Pengwu Wang ${ }^{1, a}$ \\ ${ }^{1}$ School of Accounting, Harbin University of Commerce, Harbin,150028, China
}

Keywords: System Innovation, Corporate Governance, Development potential of state-owned enterprise

\begin{abstract}
State owned enterprises are the mainstay of China's economic development. They occupy the key position and play an important role in many industries and fields in China. However, at present, the vitality of China's state-owned enterprises is lacking. The reasons lie in the backwardness of the company system and the irrational corporate governance structure. This paper analyzes the above reasons, and gives some suggestions from the aspects of innovation vitality, research potential and transformation power to provide some references for the relative researchers.
\end{abstract}

\section{Introduction}

The competition between enterprises is directly manifested as efficiency competition. There are many factors that affect the efficiency of enterprises. The author thinks there are two basic factors in it. First, the external factors, that is, whether there is a fair and orderly competition environment. Only a fair and orderly competition environment, it is possible to provide complete and accurate information, in order to evaluate the efficiency of each enterprise impartially, and then it can really stimulate and restrain the behavior of enterprises. Another aspect is the internal factors, as far as the corporate enterprises are concerned, that is, whether there is a perfect corporate governance structure in the system. The corporate governance structure is a kind of organizational structure formed by the three owners, the board of directors and senior executives, that is, senior managers. In this organizational structure, there is a certain balance between the three. Through this structure, the owners will own the assets to the board of directors of the company managed; the board of directors of the company is the highest decision-making body of the company, have to employ, senior managers of the reward and dismissal right; senior managers employed by the board of directors, the board of directors in implementing agencies under the leadership of the business enterprise, will be within the scope of authorization the board of directors. In essence, the so-called corporate governance structure is a system that coordinates the relationship between shareholders and other stakeholders. It is a contractual relationship between the company and its members. Only when the company has a perfect governance structure can the enterprise establish a complete set of sound incentive mechanism and restraint mechanism, and the company enterprise is truly efficient and energetic. The key to improve the corporate governance structure of state-owned enterprises in China is to improve the ownership structure of the company and to really define the property right. The key to improve the company's ownership structure lies in the diversification of investment entities. At present, in my listed company, the stock right is highly concentrated, and the proportion of state shares and legal person shares in the total share capital is too high.

\section{Perfect Cooperate Governance Structure Based on System Innovations}

Implement the Functions and Powers of the Board. The resolution of the shareholders' meeting is the concentration of the will of the shareholders, which determines the direction of the company's development. Once the resolution is made, it must be implemented, but because the shareholders' meeting does not directly implement the resolution that they have formed, it is implemented by the 
board of directors representing the interests of the shareholders. The resolution of the board of directors is the guideline of the board of directors on the implementation of the business. The board of directors shall not refuse to do so on any pretext. The shareholders and the board of supervisors have the right to supervise and check the implementation of the resolution by the board of directors. The board of directors is a representative of the company legal person, who has the full authority to lead and manage all the business activities of the company. In the shareholders' meeting decided the company operation guidelines and investment plans under the guidance of the board of directors have the right to arrange the production, sales and other business plans, have the right to decide the way of production and management of the company, the company has the right to determine the flow of assets, to invest in other companies or production units. However, the business plan and investment plan of the board of directors shall not go beyond the management policy and investment plan of the shareholders' meeting, otherwise it will be ultra vires, and the losses therefrom shall be borne by the board of directors. The laws of various countries all give the board of directors more extensive powers and powers, and are generally prescribed in a general way. China's law has enumerated provisions on the functions and powers of the board of directors. At the same time, the articles of association may also stipulate other functions and powers. In accordance with the provisions of the company law of China, the board of directors is responsible for the shareholders' meeting and exercises more than ten statutory functions and powers. The board of directors is divided into categories: one is to implement the resolution of the shareholders' meeting. The two is the decision-making power of major business management matters, such as the decision of the company's business plans and investment programs, the establishment of internal management institutions. Three is an important project of the right. The decision to hire or dismiss the company manager and its remuneration items, and in accordance with the nomination of the manager, appoint or dismiss the deputy manager of the company, the person in charge of Finance and the remuneration items. Only when the functions of the board of directors are implemented and the responsibilities and rights are unified, the board of directors can really assume the fiduciary duty and better safeguard the long-term interests of the state shareholders.

Strengthen Authorization System of the Shareholders. China's company law stipulates that the state-owned sole proprietorship company does not have a shareholder meeting, and the state-owned assets supervision and administration institution shall exercise the functions and powers of the shareholders' meeting. The state-owned assets supervision and administration institution may exercise the functions and powers of the shareholders' meeting by the board of directors of the Licensing companies and decide on the major matters of the company. Therefore, the board of directors of a wholly state-owned company not only enjoys the functions and powers of the general board of directors in accordance with the law, but also obtains the shareholder's authorization and has more full powers and powers. This is a feature of the functions and powers of the board of directors of a wholly state-owned company, as stipulated in the company law. It leaves both room for innovation in the reform of state-owned enterprises, and also leaves room for shareholder autonomy for the state-owned assets supervision and administration institutions. In this regard, we need to specify the scope of authorization and the conditions of authorization. In accordance with the general principles of the company law, the board of directors shall, as far as possible, authorize the board of directors to decide on the important matters of the management of the company, in addition to the inherent rights of the shareholders and the avoidance of conflicts of interest and the inability or authority to authorize them. Such as determining the company's operating principles and investment plans, and approving the company's annual financial budget plan and final accounts plan. The authorization shall be made in accordance with the specific circumstances of different companies. The company business seriously will be authorized to recover their rights to be exercised, the status of the company returned to normal after recovery or re authorization. Make resolutions on company merger, division, dissolution, bankruptcy filing, liquidation or alteration of company form. Make resolutions on the issue of corporate bonds. Resolution on the increase or decrease of registered capital of the company. Make a resolution on the company's profits distribution. To elect and replace directors and supervisors who are not represented by the staff representatives, and decide the remuneration items of 
the directors and supervisors concerned. Consideration and approval of the report of the board of supervisors or supervisor. These rights of shareholders may not be authorized to exercise by the board of directors in the formulation and revision of the articles of association. In addition, all other shareholder rights may be granted to the board of directors.

\section{Potential Enhancement of State-owned Company Based on Structure Transformation of Cooperate Governance}

Stimulate Innovation Vitality. State-owned enterprises are the dominant force in economic development, but there are still many challenges in the aspects of structural allocation and innovation ability of state-owned enterprises. This requires full mobilization of the innovative vitality of manufacturing enterprises, corporate governance as the starting point, to promote product innovation, process innovation and model innovation, to achieve the goal of transformation and upgrading. Specifically, there are three ways to stimulate the innovation vitality of manufacturing enterprises. Promote corporate governance thinking and stimulate product innovation vitality. The use of corporate governance to link production in all aspects of information, enhance product innovation and design level. Promote consumer oriented supply chain transformation, so that products can meet the current and future market demand. Enhance cloud platform technology, promote enterprise platform development, broaden the scope of product management. Application of new network technology to stimulate the vitality of process innovation. Modular management is adopted to promote the innovation of organizational structure, standardize the production process and reduce the cost of each process. Deepen online and offline collaboration, stimulate innovation in mode vitality. Encourage manufacturers to promote product online marketing and offline circulation integration, and constantly optimize the consumption path, breaking the scene restrictions, improve service levels. Support manufacturing enterprises and e-commerce enterprises in strategic investment, online sales and logistics distribution and other fields of cooperation. The basic goal of perfecting the corporate governance structure should be to protect the interests of the owners. Therefore, the owner must be in place, otherwise the mechanism for achieving the above goal cannot be produced.

Accumulate Research Potential. Development potential represents the development trend and level of the future production and operation of enterprises, and is an important basis to measure the advantages and disadvantages of enterprises. The development of corporate governance brings innovation opportunities and power to manufacturing enterprises, and these opportunities and power will constantly accumulate advantageous resources for enterprises, thus forming the development potential of manufacturing enterprises. In view of the specific situation, it is necessary to focus on the accumulation of high-end state-owned enterprises and the development potential of traditional industries. Increase research and development of advanced manufacturing technology, accumulation of high-end state-owned enterprise development potential. Support the key research areas of advanced manufacturing technology, and encourage the innovation and development of high-end state-owned enterprises. Promote the application transformation of advanced manufacturing technology, and improve the market competitiveness of high-end state-owned enterprises. The development of advanced technology with the characteristics of high-end state-owned enterprises, and accumulation of sustained development potential. The use of information resources accumulated by corporate governance, integration of cloud platform services, data-driven, for the upgrading of traditional industries to consolidate the foundation. Integrating the market, technology and capital of the corporate governance industry, providing strong impetus for the upgrading and upgrading of traditional industries. Drawing on the thinking mode of corporate governance, creating a new direction for the upgrading and development of traditional industries. In modern enterprises, the interests of the owners are not isolated, but in a reasonable structure of interests. Therefore, it is not advisable to talk about the owner's interests in terms of the owners' interests. We should be based on the situation and development trend of enterprise's property right structure, research on the relationship between the various stakeholders, handle the owners and operators of the enterprise workers interests, and through the establishment of property rights structure to adapt the rational 
interests structure, to safeguard the interests of the owners. The enterprise must solve the problem as soon as possible more personnel than work available to enterprises, by raising people into the employer, the real implementation of limited liability, on this basis to establish a modern enterprise system and perfect the corporate governance structure.

Enhance Transformation Power. For the sake of sustainable development, the state-owned enterprises need to adjust their organizational structure, business process and business model according to the external environment, improve the operation of enterprises and improve their competitiveness. In the context of corporate governance, the innovation opportunities and potential for development of state-owned enterprises need to be transformed into the driving force for their transformation and upgrading through a certain way, so as to bring into full play their value. Improve the intelligent manufacturing system, and promote the operation and management transformation of manufacturing enterprises. Promote intelligent transformation of key areas of state-owned enterprises to achieve digital manufacturing. To promote the intelligent transformation of small and medium-sized enterprises, to promote the production line automation transformation, and carry out the management information and digital upgrade pilot applications. Foster intelligent manufacturing ecosystem, and promote coordinated development of regional intelligent manufacturing. Promote cross-border integration and penetration, and promote coordinated transformation of manufacturing enterprises. Through the integration and penetration of information, leading the transformation and upgrading of traditional state-owned enterprises. Enhance the value of information resources, and promote the transformation of profit model of manufacturing enterprises. In recent decades, enterprises in many countries have implemented employee sharing system, and workers have also shared part of the business interests of enterprises, and the structural relationship of interests has undergone new changes. Large Japanese companies are most visible in this respect. They implement the wage system based on seniority, actually by the operation and development of enterprises take part of the risk, young people entering the enterprise, pay a relatively low starting point, with the increase of age and gradually improve, at lower wages than contribution, to achieve balance, finally wages more than contribution, in this case, only the enterprises continue to survive and develop, their seniority "reserves" in order to cash. Through the interconnection of corporate governance, the implementation of internal coordination of the industry chain, integration and upgrading of manufacturing enterprises production methods.

\section{Conclusion}

A systematic project is needed to deepen the reform of state-owned enterprises, and corresponding regulatory measures should be put forward on the basis of a more accurate analysis of the market environment. Institutional innovation on the basis of practice is beneficial to the change of corporate governance structure. The transformation of corporate governance structure can further stimulate the vitality of enterprise development.

\section{Acknowledgements}

The research is the result of General Project of Science Research Subject of Chinese Accountants of the State Ministry of Finance in 2015 named Research on Mixed Ownership and State-owned Capital Management (Grant No. 2015KJB028), General Project of Province Level of Innovation and Entrepreneurship Training Plan of University Students in 2017 named System Innovation, Corporate Governance and Development Potential of State-owned Enterprise-Taking Heilongjiang Province as an Example (Grant No. 201710240034), Key Project of University Level of Teaching Reform and Research of Harbin University of Commerce in 2016 named Countermeasures of Abilities Cultivation of Independent Innovation and Entrepreneurship of Accounting Postgraduates in the era of “Big Data, Intelligence, Mobile Internet and Cloud Computing” (Grant No. HSDJY05(Z)). 


\section{References}

[1] Jin Xiaoyan. Government Regulation, Corporate Governance and Executives' Remuneration Restraint Mechanism of State-owned Enterprises [J]. Journal of Zhengzhou University, 2016, 49(2): 59-63+159.

[2] Luo Hong, Zeng Yong-Liang, Liu Baohua. Executive Compensation, Corporate Governance and Cost Stickiness in State-owned Enterprise [J]. Economic Survey, 2015, 32(2): 99-104.

[3] Hu Jianguang, Mao Zhihong. Corporate Governance Issues of State Owned Enterprise Deepening Reform: Regulation and Incentives [J]. Journal of Social Sciences, 2016(7): 48-56.

[4] Gao Wenliang, Cheng Peixian. Government Control, Management Agent Motivation and State -owned Enterprise's Corporate Governance [J]. Joumal of Shanxi Finance and Economics University, 2012, 34(6): 86-95. 